\title{
Moral Education at Work: On the Scope of Maclntyre's Concept of a Practice
}

\author{
Matthew Sinnicks ${ }^{1}$ []
}

Received: 12 June 2017 / Accepted: 23 November 2017 / Published online: 1 December 2017

(C) The Author(s) 2017. This article is an open access publication

\begin{abstract}
This paper seeks to show how MacIntyre's concept of a practice can survive a series of 'scope problems' which threaten to render the concept inapplicable to business ethics. I begin by outlining MacIntyre's concept of a practice before arguing that, despite an asymmetry between productive and non-productive practices, the elasticity of the concept of a practice allows us to accommodate productive and profitable activities. This elasticity of practices allows us to sidestep the problem of adjudicating between practitioners and non-practitioners as well as the problem of generic activities. I conclude by suggesting that the contemporary tendency to regard work as an object of consumption, rather than undermining MacIntyre's account of practices, serves to demonstrate the potential breadth of its applicability.
\end{abstract}

Keywords MacIntyre $\cdot$ Virtue ethics $\cdot$ Practices

\section{Introduction}

Despite his own scepticism about business ethics, Alasdair MacIntyre has been extremely influential within the field, and, as Ferrero and Sison (2014) note, has been cited in the business ethics literature more often than any virtue ethicist other than Aristotle. This influence is due in large part to MacIntyre's concept of a practice. There have been a number of scholarly contributions to the literature on MacIntyre and business ethics which have explored the concept of a practice (such as Beadle 2008, 2013; Beadle and Knight 2012; Beabout 2013; Garcia-Ruiz and Rodriguez-Lluesma 2014; McPherson 2013; Moore 2002, 2012a, b, 2015). As this literature reveals, the concept remains the subject of much debate amongst business ethicists. Furthermore, there have been numerous articles which aim to show that some particular activity or form of work fits MacIntyre's description of a practice. Examples include business (Kay 1997), management (Brewer 1997), nursing (Sellman 2000), public relations (Leeper and Leeper 2001), teaching (Dunne 2003), journalism (Borden 2007), fire-fighting (Dawson 2014), investment advising (Wyma 2015), and accounting (West

Matthew Sinnicks

matthew.sinnicks@northumbria.ac.uk

1 Northumbria University, Room 248, City Campus East 1, Newcastle upon Tyne NE1 8ST, UK
2016). The frequency with which such cases for particular forms of employment counting as practices are made suggests that the scope of MacIntyre's concept of a practice is not entirely clear. In this paper, I explore this concept, focusing in particular on the notion of engagement in a practice, with the aim of elucidating how MacIntyre's ethical theory might be applied to business ethics.

One of the main reasons MacIntyre's concept of a practice has been appealing to business ethicists is that it, potentially at least, seems to "offer the best understanding of the promise of work" (Muirhead 2004, p. 167) and provides a model of what human production could be like at its best (Keat 2015, p. 202). This is because it is, again potentially, able to show how good work can be both intrinsically satisfying and morally educative. Indeed, this potential is why it is worth exploring the scope of MacIntyre's concept. Many business ethicists remain sceptical about the worth of MacIntyre's work and have questioned whether it can be applied to market-driven institutions (e.g. Dobson 2009; Hartman 2013, 2015). Any attempt to apply MacIntyre's thought to business ethics is likely to be critical of the avarice characteristic of certain parts of advanced capitalist society, and indeed MacIntyre himself suggests that avarice ('pleonexia') is a "highly valued character trait", even "a duty" (2016, p. 127), in contemporary capitalist society. However, in this paper I aim to bolster the argumentative resources of those who think 
MacIntyre's work can be, and is, a valuable tool for business ethicists and organisational scholars both by offering a close reading of MacIntyre's concept of a practice and by analysing the concept of engagement in practices.

In the following section, I outline the concept of a practice and highlight a series of challenges facing MacIntyre posed by Hager, which lead him to suggest we must 'refurbish' MacIntyre's concept. These are: (1) the problem of accounting for "practical and productive activities" (Hager 2011 , p. 548) which are more intimately bound up with the pursuit of external goods than non-productive practices, an issue which has also been raised by a number of other commentators, (2) the problem of adjudicating between who is and who is not engaged in a practice, and (3) the problem generic activities pose for our ability to set boundaries between related practices.

I aim to offer a response, albeit a sympathetic one, to these challenges. I do so first, by arguing that there is an important asymmetry between what might be called predominantly productive and predominantly non-productive practices. There are several reasons for this. Firstly, predominantly productive practices that aim at some distinct social good beyond themselves (e.g. farming, which aims to produce food) are not susceptible to the historical progression characteristic of the more clearly paradigmatic and predominantly non-productive practices (e.g. physics). Secondly, accounts of productive practices typically appeal to the broader community in which the practice is housed, such as a fishing village (MacIntyre 1994), to a degree that is not the case in accounts of more paradigmatic, non-productive practices, e.g. various arts and sciences. Thirdly, there seems to be a key difference in the criteria for excellence in productive and non-productive practices. Nevertheless, I suggest this does not undermine the applicability of the concept to productive activities, it simply means we need to look more closely at the concept of engagement in a practice. I then seek to respond to Hager's second and third challenges by doing just this. I argue that even a relatively minimal engagement in a practice can, in principle, be morally educative. Even if we cannot provide necessary and sufficient conditions for either engagement in a practice or for the conceptual boundaries of any particular practice, the concept is not thereby undermined.

In the final section, I draw on some existing research inspired by MacIntyre to outline the prospects for applications of MacIntyrean research in business ethics. I will ultimately conclude that MacIntyre's work can be used to explore the ethical quality of work beyond employment in paradigmatic practices and that the tendency to regard work as an object of consumption is more ethically promising than it may appear.

\section{The Concept of a Practice}

MacIntyre outlines a neo-Aristotelian conception of virtue, at the core of which is his notion of a practice. The term 'practice' has been widely employed by philosophers, and MacIntyre's use differs from that of figures such as Wittgenstein, Sellars, and Brandom (see Knight 2008, 2013 for detailed discussion of how MacIntyre's concept compares to these alternatives). Practices, for MacIntyre, are those activities which possess complex internal goods, are intrinsically rewarding, and serve as the primary basis of his account of the virtues. To this basis in practices, MacIntyre adds the concept of the narrative unity of human life, the concept of traditions of enquiry (2007 [originally published 1981]), which received further elaboration in later works (1988, 1990; see also Lutz 2004; Nicholas 2012), and a conception of flourishing rooted in human biology (1999), each of which is necessary for a full understanding of the virtues. Practices, however, are of vital importance and provide the conceptual bedrock of MacIntyre's ethical theory. According to MacIntyre's definition, a 'practice' is a:

coherent and complex form of socially established co-operative human activity through which goods internal to that form of activity are realized in the course of trying to achieve those standards of excellence which are appropriate to, and partially definitive of, that form of activity, with the result that human powers to achieve excellence, and human conceptions of the ends and goods involved, are systematically extended. (2007, p. 187)

Despite the prolixity of this definition, practices are not to be regarded as esoteric activities available only to a few, but rather as a ubiquitous feature of human societies, and present in every human life. Even if practices are central in some societies and relatively marginalised in others (2007, p. 193), all of us engage in practices of one sort or another. As Knight says, it is "by participating in shared social practices that we come to learn the reality of goods other than the satisfaction of our socially 'untutored' desires" (2009, p. 117). While, as Keat (2008) points out, MacIntyre's account of the good is not comprehensive, something MacIntyre readily admits (e.g. 2008a, p. 268; 2016, p. 315 ), his concept of a practice nevertheless provides a powerful basis for an account of moral education and of the ethically ameliorative role good work can play in our lives.

Practices require us to acquire the virtues because it is only through virtue acquisition that we can properly experience the internal goods practices make available. On MacIntyre's view, our attempts to improve ourselves 
so as to master some rewarding activity are more effective as a moral education than any formal ethics course could be (see MacIntyre 2015). Some virtues, such as justice, truthfulness, constancy and courage, are required by all practices, and thus practices are well placed to enable us to develop a good character. Unless we are prepared to give and receive honest criticism, for example, we will never be able to experience the satisfactions practices can provide. Virtues are not only, or even especially, exhibited in the context of practices, but they are learned in such contexts. As MacIntyre says, "the exercise of the virtues is something learned in the context of practices... those who engage in practices need the virtues if they are to achieve the individual and common goods internal to practices" (2013, p. 216). So, not only are practices intrinsically satisfying and inherently worthwhile, they are also morally educative. Indeed, just as virtues are internal rather than external means to the end of human flourishing in the Aristotelian tradition, practices are internal means to virtue acquisition.

MacIntyre illustrates the concept of practices with the following examples: architecture, chess, portrait painting, physics, football and farming. By contrast, bricklaying, throwing or kicking a ball with skill, and turnip-planting, are not practices (2007, p. 187). What are we to make of MacIntyre's list of examples? It is possible, given that practices can only be fully understood by those with relevant experience, that MacIntyre is mistaken about some particular example and has underestimated the goods inherent to bricklaying, for instance. However, taken as illustrations rather than a canonical list, they serve their purpose.

Farming, the most obviously productive practice on MacIntyre's list of examples, is more complex and socially established than turnip-planting. It might be tempting to think that farming deserves the status of practice, whereas turnip-planting does not, on the grounds that the former is more enjoyable. However, as Beadle and Knight (2012) have shown, MacIntyrean accounts of work must resist appeals to mere subjective satisfaction, even if, as I will argue later, subjective satisfaction is a necessary component of engagement in a practice. According to MacIntyre, "a practice, in the sense intended, is never just a set of technical skills, even when directed towards some unified purpose and even if the exercise of those skills can on occasion be valued or enjoyed for their own sake" (2007, p. 193). Unusual cases of people becoming fascinated and delighted by simple, incoherent or horrible activities are, therefore, never to be regarded as counter-examples. Rather than seeing MacIntyre's definition as an austere and perhaps arbitrary stipulation regarding which activities can provide a basis for his definition of virtues, we should read it as a considered description of the sorts of activities that are morally educative and intrinsically rewarding as a result of their distinctive qualities. Thus, the central question is whether some form of activity is befitting the most worthwhile kinds of human life we can imagine, given the sorts of creatures we are.

Practices must have a coherent core to allow for the gradual progression of standards of excellence and must be complex in order to be able to be sufficiently challenging and fulfilling. This complexity is what prevents engagement in a practice from becoming monotonous. Non-complex activities, such as planting turnips or throwing a ball, will not be morally educative as they will not require the virtues. Although such activities may require much repetition, this does not imply that they can teach us perseverance, as the virtue of perseverance is only what it is when it serves some worthwhile end.

The process of learning required to be a 'master' turnip planter, if this concept is intelligible, is insufficiently complex to generate the reflection and commitment required by practices, and as such does not exhibit the other definitive features of practices. For example, simple activities will not be cooperative in the requisite sense. Practices must also be cooperative because we are typically unable to correct our own mistakes when beginning to engage in a practice, and are sometimes incapable even of perceiving those mistakes. This brings us to another key feature of practices: the role played by a particular community of practitioners within a particular tradition of practice. MacIntyre claims that to,

enter into a practice is to enter into a relationship not only with contemporary practitioners, but also with those who have preceded us in the practice... Practices never have a goal or goals fixed for all time - painting has no such goal nor has physics - but the goods themselves are transmuted by the history of the activity. (2007, p. 194)

In attempting to master a particular practice, we must engage with and learn from our contemporary fellow practitioners, with whom we can discuss the practice, share advice, and give and receive encouragement and criticism. It is with these fellows that we are able to discuss the relevant standards of excellence which go beyond any subjective enjoyments provided by the practice in question, and in this sense practices also have a significant historical element, which we will return to below with reference to the asymmetry between productive and non-productive practices.

The most important element of MacIntyre's definition of a practice is that of internal goods, which are to be contrasted with external goods. External goods, for MacIntyre, include power, prestige and money, which can always be secured in a variety of ways. Internal goods, by contrast, can only be achieved by engaging in the particular practices they are partially definitive of. For example, a painter might sell a painting, but the money thereby acquired could have been acquired by gardening, telemarketing, or theft. 
The money earned by the sale is only contingently related to the activity of painting. The internal goods of painting, on the other hand, cannot be achieved by engaging in other activities. External goods are good and must be secured by institutions which support practices in order to protect those practices. Nevertheless, whereas external goods are always someone's property and possession (2007, p. 188), internal goods are not limited in this way, and so are not liable to be part of a zero-sum game. The concept of internal goods most clearly reveals how practices are morally educative because the pursuit of internal goods requires us to develop the virtues. Without discipline and self-honesty, for instance, no painter will be able to improve. Without humility, no painter will be able to subordinate him or herself to the standards of excellence characteristic of painting's community and history. The intrinsic joys provided by practices give us a reason to attempt to acquire the virtues. Moreover, once a virtue has been properly acquired, it can be exhibited outside of the context in which it was learned, and ultimately valued in itself.

The concept of a practice has been criticised in a variety of ways. Lutz (2004) deals expertly with objections from relativism (Wachbroit 1985) and the possibility of evil practices (Feldman 1986), amongst others. Here, I focus on three 'scope problems' put forward by Hager (2011), all of which threaten to undermine the applicability of MacIntyre's concept. The first scope problem relates to the lack of consideration productive activities receive in MacIntyre's account of practices: unless it can be shown that productive activities answer to MacIntyre's definition of a practice, the concept will be inapplicable to the field of business ethics and many other areas of practical concern. Secondly, it is not clear who is to be included in the community of practitioners. This is because MacIntyre is not clear about the kind and degree of experience necessary for inclusion. Thirdly, it is not clear whether, for instance, portrait painting and landscape painting are separate practices or whether the generic activity of painting covers both. If we are unable to adequately distinguish between practitioners and non-practitioners or unable to adequately distinguish between different practices, then it seems that the concept will remain unhelpfully vague, and so again will be limited in terms of applicability.

In the following section, I will explore the charge that MacIntyre's concept cannot account for productive activities. I concede that Hager's allegation is not without warrant, and accept that there is an asymmetry between productive and non-productive practices, but I argue that we can nevertheless make sense of certain productive activities as practices, and offer a close reading of MacIntyre's discussion of practices in order to establish this. In order to properly answer Hager's charge, I then go on to elaborate on the limits of engagement in a practice, and argue that the conditions for community membership in the relevant sense are necessarily broad and blurred. In highlighting this elasticity, and arguing that we need not be procrustean in our understanding of practices, I also hope to defuse Hager's third challenge, the problem of generic activities.

\section{Progress and Production in Practices}

According to Lawton and Páez, the question of whether leadership or business count as practices is unresolved (2014, p. 643), which suggests that the scope of the concept is in need of clarification. However, this concern is not new. Ever since Hauerwas and Waddell (1982) questioned MacIntyre's decision to include architecture but exclude bricklaying in his original set of examples, there have been recurrent suggestions that MacIntyre's concept does not adequately apply to predominantly productive activities. Hartman notes that MacIntyre "does not give an adequate account of the circumstances under which work may be intrinsically good" (2015, p. 167), and indeed spends much time detailing the ways in which MacIntyre's ethics does not satisfactorily apply to the contemporary corporation. Similarly, Miller has argued that MacIntyre's definition works in cases where the practice "consists entirely in the internal goods achieved by participants and the contemplation of those achievements by others" (1994, p. 250), but not in cases of productive activities. Because all businesses must be 'productive' in some sense, this charge must be answered if MacIntyre's concept is to be applied to the kinds of productive enterprises in which much modern work takes place.

Hager notes that MacIntyre "was strongly influenced by examples of games with not enough consideration being given to other practical and productive activities" (2011, p. 548). MacIntyre does indeed repeatedly illustrate his concept with reference to "games, sciences and arts" (2007, p. 190) and spends considerably less time discussing productive activities. At this point, it may seem that MacIntyre is guilty merely of a sin of omission, which may be rectified simply by elaborating on the goods internal to a productive practice or two. However, there are deeper reasons for thinking MacIntyre's account of practices struggles to apply to productive activities. These include: (1) the historicism present in MacIntyre's definition of a practice, (2) an additional reliance on references to the wider community in the case of productive practices, and (3) the fact that standards of excellence typical of productive and non-productive practices are different. My aim is to explain why productive practices may be regarded as a problem for MacIntyre, and to show that the most effective to deal with this worry is to concede that there is an important asymmetry between productive and non-productive practices, but to argue that this does not undermine the possibility of productive practices. 
The inherent difficulty of accounting for practical and productive activities as practices becomes apparent when we return to MacIntyre's definition of practices. Consider the final clause in MacIntyre's definition of a practice, the requirement that the realisation of goods internal to a practice must have "the result that... human conceptions of the ends and goods involved are systematically extended" (2007, p. 187, my emphasis). It is this final clause that threatens to put the concept at odds with productive activities and presents an even greater challenge than Hager suggests. The requirement seems to rule out turnip-planting, but it also threatens to rule out farming because this 'systematic extension' seems to require a strongly historicist reading of the concept of a practice, in the sense that only those able to contribute to the historical development of an activity could be considered practitioners.

Farming and turnip-planting both have ends and goods, but is it far from clear exactly how these are to be systematically extended. In elaborating this final and crucial clause of his definition, MacIntyre claims that practices do not have set and stable goals, but rather that "the goods themselves are transmuted by the history of the activity" (2007, p. 194). Great painters and physicists transform their disciplines, and these activities have histories characterised by systematic extensions of conceptions of ends and goods internal to them. This is not, however, true of the history of MacIntyre's examples of paradigmatic non-practices: turnipplanting, tic-tac-toe or bricklaying. In this respect, farming seems to be closer to turnip-planting than it does to physics or painting. This is because farming seems not to have undergone the overarching transformations characteristic of the arts and sciences, in which the greatest practitioners have implemented audacious new ideas that have revolutionised the practice, and in which practitioners are conscious of, and partially in dialogue with, the greats of the past. Qua productive practice, farming is not-or rather, given that we cannot foresee the future of farming, does not seem to be-characterised by the historical development typical of arts, games, and sciences, i.e. the more paradigmatic examples of practices.

Farming has indeed changed over time, with the advent of new technologies and growth in relevant scientific knowledge, or due to changing attitudes to issues such as pollution and organic food, but this history is not characterised by the same transmutation of goals as the histories of painting or physics. Where farming has changed significantly, in terms of fertilizers, machinery, and selective breeding, the change has come largely from developments in other practices, such as chemistry, engineering, and genetics. Such changes have increased efficiency and have helped develop new techniques and strategies appropriate to farming, but they have not systematically extended our understanding of the ends of farming. They are simply not those kinds of changes. The internal goods we might associate with farming, such as stewardship of the land, and the joys of cultivating animals and plants, do not seem to be susceptible to the historical progression characteristic of the more clearly paradigmatic practices.

A farmer who travelled in time from the twelfth century to present would be amazed by how farming is carried out, but not by what farming is trying to do. A twelfth-century painter would be amazed by both the techniques and the aims of contemporary painting. MacIntyre seems to have something similar in mind when he notes that "a farmer has to arrive through her or his work at a highly particular set of notions of what good farming is on this particular terrain, in this particular climate, with this kind of plough, and this kind of labor force", whereas "the musician or the painter may be as surprised as anyone else when the end to which they have directed their activities emerges as this performance or that portrait" (2016, p. 50 emphasis in original). The practice of farming may deal in particularities, but painting and music allow for surprises.

To conclude from this, that productive activities are excluded from the realm of practices would be incorrect, however. Although MacIntyre is not entirely clear about what he means by 'systematic extension', he does leave clues about how we might rescue the notion of a practice from this excessively historicist reading. MacIntyre notes that practices are "those modes of activity within which ends have to be discovered and rediscovered, and means devised to pursue them" $(2007$, p. 273$)$. If it were only the case that ends had to be discovered, then it would be hard to resist a strongly historicist reading that would rule farming and most productive practices out of contention for the status of practice, but as the rediscovery of ends is part of a practice this need not be so. A systematic extension need not be aggregative. Instead, we should read 'systematic extension' as contrasting with piecemeal extensions, i.e. extensions in which one aspect of a practice is extended without that extension having some relevance to a greater whole.

When someone is in the process of becoming a farmer, he or she does not learn how to carry out one task in isolation from how it is interconnected with a whole host of other tasks. Here, we have a way of understanding the 'systematic extension' clause that is not only compatible with the weaker historicism of the rediscovery of ends, but one which also fits well with the observation that engagement can be partial. The distinction between discovery and rediscovery is similar to Boden's (2003) distinction between historical and psychological creativity. We may well want to privilege historical creativity, i.e. the kind of creativity which leads to new ideas arising for the first time in human history, when accounting for what is most valuable overall, but it is the psychological experience of creatively engaging in an activity, of discovering its ends and goods for oneself, that is both intrinsically satisfying and most important to an account of 
moral education. We will return to the topic of the subjective experience of goods in the final section.

An understanding of 'systematic extension' in which ends are only discovered rather than both discovered and rediscovered would suggest that only those activities in which creativity and novelty are part of the aim, such as arts, games, and sciences, could count as practices and perhaps even that only those capable of significant innovations could count as genuine practitioners, clearly ruling out the partially engaged, a category which arguably includes managers and employees in practice-related industries, a point we will address in the following section. This is because an outright, sui generis discovery is liable to change the practice as a whole. In this case, the likes of Einstein, Picasso, and Rod Laver would be almost alone as practitioners in the twentieth century, joined only by a relative handful of other innovative greats. A systematic extension that involves the rediscovery of internal goods, on the other hand, allows that individual practitioners and groups of practitioners can deepen their understanding of a practice by rediscovering for themselves what prior and contemporary practitioners have already learned. So, when a farmer or a painter or a physicist learns the skills necessary to partake in those respective practices, they are personally discovering and historically rediscovering the ends and goods involved.

If this account is correct, the fundamental asymmetry between predominantly productive and predominantly nonproductive practices would remain, productive practices would still not typically possess goods "transmuted by the history of the activity" (ibid, p. 194), but we are better placed to see how productive activities can be made sense of in MacIntyrean terms. An examination of the notion of 'systematic extension' shows that we can make sense of productive activities as practices. So, while Hager is probably correct to say that MacIntyre's own discussion in After Virtue paid less attention to productive activities than would have been ideal, this lack of attention, perhaps inevitable in a work of such breadth, is not seriously damaging.

This brings us to the second reason for accepting an asymmetry between productive and non-productive practices: the role played by the relevant community. In MacIntyre's (1994) discussion of productive practices, in which he gives the example of the fishing crew as a practice-based community, the kind of life provided by membership of that community takes centre stage. The key motivating goods are "the goods of the common life of such a crew" (MacIntyre 1994, p. 185), and the life of the fishing village as a whole is given special prominence. Indeed, in this example the activity of fishing itself, and the internal goods it may provide, is probably secondary to participation in the community, a community which is not focused on the goods internal to fishing in anything like the same way as a chess club is focused on the goods internal to chess. Indeed, MacIntyre claims that the good of a fishing crew is inherently bound up with "three related common goods, those of family, crew, and local community" (2016, p. 179).

Given MacIntyre's Aristotelian understanding of politics, which involves the making and sustaining forms of human community (2007, p. 195) as opposed to engaging with large-scale nation states, this suggests that productive practices are intimately related to the practice of politics. Community membership is at the core of engagement in productive practices, whereas in non-productive practices the role of community remains crucially important, but is not quite as central. In predominantly non-productive practices, engagement supports and facilitates a pursuit of the goods distinctive of the activity in question, which can be specified independently of that communal support even if they are not, as a matter of fact, really available without it. By contrast, "[i]ndividuals who farm need to regard themselves as contributing to a larger project" (2016, p. 171), which suggests the goods internal to farming make necessary reference beyond those distinctive goods. The practice of politics, and the reliance on the role played by the community, highlights how different alleged examples of productive practices are from more paradigmatic, predominantly non-productive cases.

Clearly, we can enjoy both the intrinsic rewards and the moral education provided by chess even if we are only occasional players, as is the case in most engagement in practices. Most people who play chess do not do so professionally, nor indeed do they join chess clubs. Likewise, most engagement in productive activities, including productive practices, tends to be part of paid employment. However, this is not to deny that the role a practice plays in someone's life is important. Again, we can admit an asymmetry between predominantly productive and non-productive practices while retaining the view that this asymmetry does not imperil the category of productive practice. However, there are greater challenges in the case of productive practices, which will sometimes be best approached as though they are sites of the practice of politics, as Sinnicks (2014) has suggested, a topic we will return to below.

As I suggested above, there is a third reason to believe that a fundamental asymmetry exists between productive and non-productive practices: to excel in a productive practice requires us to be more concerned with outcomes than is the case in non-productive practices, and often continued employment will depend upon successfully delivering such outcomes. This is perhaps the most important of the three reasons for recognising this asymmetry. Most engagement in a practice is concerned with outcomes to some degree. Chess players aim at victory, after all. However, it is possible to lose regularly at chess and still be an excellent player. This may be because the competition consists of other excellent players, or where one possesses some particular strategic 
deficiency that undermines otherwise excellent play. This is in contrast to productive practices like farming, or in business more generally. Periods of severe drought notwithstanding, it scarcely makes sense to describe someone as an excellent farmer if he or she regularly fails to produce food. This is not to say that the goods of farming are limited to producing food, but it does suggest that engagement in a productive practice requires a prioritisation of certain external goods that far exceeds that present in predominantly nonproductive practices. This basic principle holds of business more generally, and any business which fails to be productive in this sense will not be a business for long.

If there were a way to vastly increase the efficiency of farming, and therefore at least one of the external goods of farming, so that more food be produced or less land used, at some cost of its internal goods, then we would ordinarily expect a good farmer to judge it to be worth losing some of the distinctive satisfactions of farming for that greater productivity. Not only has this happened to a significant degree, but much farming today seems to be rather disconnected from any internal good. While it is possible that the hope MacIntyre holds for farming is a result of a "romantic aversion to urban life" (D'Andrea 2006, p. 425), the growth of industrial farming has meant that the work carried out by agricultural machine operatives, and the work that takes place on factory farms, is about as far from MacIntyre's description of a practice as an occupation can be. By contrast, no increase in efficiency at producing a victory in chess-by, per impossibile, memorising complex and hitherto unknown checkmate 'tricks' - would justify sacrificing the goods internal to chess, and nor does it seem possible for chess to become as disconnected from its internal goods as it is for a productive activity such as farming. If a predominantly productive practice could be made vastly more efficient through greater automation, then we would likely implement such a change. We would not, however, want chess to be played only by automatons, no matter how brilliant.

This important difference allows some kinds of practices, i.e. non-productive practices, to be relatively unconstrained, and so gives the relevant practitioners the scope to transform their practices so that conceptions of ends and goods can be extended. Truly excellent artists change the art community's understanding of great art by revealing the possibilities of art itself, but the opportunity for those engaged in productive practices to excel in this way is, if not entirely absent, then at least severely reduced, as I noted earlier.

This asymmetry suggests that engagement in productive practices is likely to be less obvious than it is in more paradigmatic cases. The examples given at the outset of applications of the concept of a practice have focused on jobs such as management, investment advising, PR, etc., rather than on more obviously paradigmatic examples such as chess, painting and so on, precisely because the former are contentious cases, whereas the latter obviously answer to MacIntyre's definition. Productive practices are compromised by necessity. They must necessarily aim at something other than the excellences and goods characteristic, and indeed partially definitive of, the practice itself. This is the essence of MacIntyre's critique of market economies. The necessary focus on success, understood in terms of external goods, serves to undermine the extent to which devotion to internal goods is possible. However, it need not destroy such devotion. Indeed, there is significant scope for individuals who are appropriately committed to goods internal to productive practices to pursue them. This pursuit may not always be easy, as the example of Elaine the fictional architect running through Moore's Virtue At Work (2017) suggests. In this illustration, Elaine's love of excellent buildings and her appreciation of the creativity characteristic of her work-when things are in good order-allow her to avoid the countervailing pressure working in a productive practice can exert. While this pressure may serve to push those engaged in productive practices in the direction of the periphery, as it were, there is no reason to think that they are pushed all the way, as Moore's example demonstrates. It does mean that there are limits to what conceptual accounts of particular activities can achieve, however, and it does mean that in order to defend MacIntyre against Hager's challenge we need to look more closely at the notion of engagement in a practice.

\section{The Limits of Engagement}

Hager claims that "MacIntyre's examples leave it unclear what the criteria are for inclusion in communities engaged in a practice" $(2011$, p. 550). If this is so, then it seems that the practical applicability of the concept must be called into question. As we have seen, MacIntyre offers a detailed definition of practices, but if good grounds for including or excluding particular agents from the category of practitioners are lacking, then the concept will be of little empirical use. While Hager's concerns are well founded to some degree, this is due not to a fault in MacIntyre's explanation of the concept, but rather to the nature of practices as activities which can be fully appreciated only by the initiated, and admit gradations of engagement. Therefore, my aim in this section is to defuse Hager's challenge by offering an analysis of the concept of engagement in a practice. In order to do this, I explore the elasticity of the concept of a practice and argue that this elasticity is not seriously problematic. If those at the fringes of a practice can still be morally educated by it, then it is unnecessary for MacIntyre, or those who seek to apply his work, to be able to provide specific criteria regarding precisely where the border between practitioner and non-practitioner lies. Aristotle wisely counsels that "we 
should not seek the same degree of exactness in all sorts of arguments alike" (NE 1094b), and the nature of practices means some ambiguity will be inevitable. Indeed, we should be wary of trying to construct a procrustean concept of practices. The inscrutability of practices to the uninitiated renders general applications of the concept problematic, and so decisions about the limits of engagement in any particular practice are best left to masters of the relevant practice. However, this question of scope becomes more pronounced when we consider the relatively porous border between practitioners and non-practitioners.

When discussing the relationship between practitioners and their relevant communities, MacIntyre says "whether we are painters or physicists or quarterbacks or indeed just lovers of good painting or first-rate experiments or a wellthrown pass", we must subordinate "ourselves within the practice in our relationship to other practitioners" (2007, p. 191). He also notes that the "enjoyments of those who play games as different as soccer, cricket, and chess with great skill are matched by the enjoyments of those spectators who combine an appreciation of those skills with the devotion of fans" (2016, pp. 132-133). This means that those at the periphery of a practice are engaged in it, albeit partially, and can therefore be considered practitioners too. This is one reason why scholarly discussions of the concept are not entirely self-defeating. While practices are cognitively closed to some degree, partial engagement means that those who have not mastered a practice can have some understanding of that practice, and write meaningfully about it for an audience of non-masters. Lovers of great paintings who do not themselves paint can be morally educated by their role as practitioners, diners as well as chefs can derive more than aesthetic pleasure from excellent cookery, and "the high school physics teacher and the analyst of the data provided by the Large Hadron Collider are contributing to one and the same enterprise" (MacIntyre 2013, p. 209).

Those at the periphery of a practice may not have the intimate experience of the relevant internal goods of master-practitioners. However, they must nevertheless develop certain virtues in order to be able to appreciate the goods internal to that practice. They must still recognise their initial ignorance and need for tuition, etc., and so there remains a possibility that such an engagement will be morally educative. Because engagement can be partial, participation in practices need not be monomaniacal for their ethical effects to be felt. The notion that lovers of a well-thrown pass are engaged in a practice, and can therefore be morally improved by this love, goes some way towards showing how ubiquitous practice-engagement can be and is.

An engagement in practices that is both far from all-consuming and is very much concerned with the achievement of external goods can still be morally educative. To illustrate this, I will draw on the example of sports and sports fans. Just as in business, where "interpersonal competition is expected, accepted, praised, and routinely encouraged" (Pfeffer and Sutton 2006, p. 64), the sports fan's engagement with the sport in question may often be inseparable from the enjoyment of competition and the desire for victory (though not all victories are equal, and we will come to the importance of personal commitment to internal goods below). This may distinguish it from the less adulterated focus on internal goods characteristic of an engagement in non-competitive practices, but this does not rule out an appreciation of the relevant internal goods entirely.

Indeed, sport provides an especially useful example for three reasons. Firstly, sports are typically paradigmatic examples of practices, secondly, engagement in them tends to be partial rather than all-consuming, and thirdly because they straddle the productive/non-productive divide to some degree, given that sports are industries as well as practices. Sport provides, therefore, perhaps the clearest connection between the 'ethics of amateurism', which seems to fit most naturally with MacIntyre's discussion of practices, and business ethics, i.e. the ethics of a domain in which profit and productivity are of vital importance. As such, the example of sport allows us to raise questions relevant to an application of MacIntyre's ethics to business ethics without entering into contentious debates about which particular industries and businesses count as practices and practice-based communities.

One possible objection to consider here is that the level of engagement characteristic of sports fans is simply not meaningful enough to lead to the moral education practices ought to be capable of providing and that it is intuitively implausible to claim that people on the fringes of a practice, a lover of great painting or a well-thrown pass, can actually acquire virtues from their apparently passive admiration for the work of others. It may seem deeply counter-intuitive to claim that such fans can acquire virtues from so minimal an 'engagement' in a practice, i.e. by simply watching their favourite sports teams or athletes, given that passivity of such an activity if nothing else. Our ordinary experience of persons who have seriously committed themselves to practices like chess or physics, or indeed particular sports, makes it intuitively plausible that their engagement with the practice in question can provide a moral education, and it would hardly be a bold conjecture to suggest that our experience of sports fans is rather different from this.

However, there are two points worth making here. Firstly, we should note that MacIntyre refers to "lovers of a wellthrown pass" (my emphasis) and not to partisan fans who simply support their team. Such fans may care only about whether their team achieves the external good of victory, and be unconcerned with whether that victory is achieved by fair means or foul. Even minimal engagement in the sense required presupposes a respect for the internal standards of 
excellence definitive of the sport in question, a respect that increases the intrinsic satisfactions of being a spectator [a category Hager suspects will be excluded from the community of practitioners (2011, p. 550)]. This means that a MacIntyrean position on the morally educative power of spectatorship will have some affinity with Mumford's account of the aesthetics of spectatorship. Mumford aims to bring "the aesthetics of art and sport... closer together" (2012, p. 7) and suggests that in this regard there is a distinction to be made between partisan fans, who support one team, and purists, who "watch sport for more aesthetic and intellectual reasons" (ibid). This is not a hard and fast dichotomy, but it seems likely that any moral education resulting from spectatorship will require at least some degree of purism, in Mumford's sense, even if the likely focus on success acts as a countering force, as I suggested above. In MacIntyre's recounting of the life of CLR James, he notes that the latter saw cricket as "an art, just as literature and music are" (2016, p. 289) and something that can teach us the virtue of restraint (ibid, p. 275) as a "tradition of thought, judgement, and action" (ibid, p. 289). As a gifted intellectual and journalist, James may be an exceptional case, but there is no reason why this form of understanding cannot be more broadly available. This takes us on to the second point.

Just as engagement can be partial so can virtue acquisition. Someone who cares about the internal goods of a sport may well be dissatisfied if his or her team employs underhand tactics, openly harangues officials in the hope of pressuring them into giving favourable decisions, and generally behaves in a cynical fashion. A fan may also raise questions about owners of teams, and may be dissatisfied with owners who treat their favoured teams merely as profit-seeking enterprises, and thus without regard to the distinctive goods of the sport in question. Such a fan may have developed a subtle and sophisticated grasp of the tactics, and have expanded his or her intellectual capabilities in so doing, or had a chance to develop the virtues of diligence or patience through the study of tactics and their best application. He or she may also have begun to develop the excellences of character required to fully appreciate the aesthetic qualities of the sport in question, or begin to appreciate the importance of teamwork and courage as exemplified by the athleteswho are, ceteris paribus, more deeply engaged practitioners-themselves. In both cases, the sports fan may have had to display the humility and self-honesty to recognise that other members of the relevant community (be they historians, insightful journalists or pundits of the sport, or simply more experienced fellow fans) possess a greater degree of expertise and so a greater ability to judge. No one goes from knave to megalopsychos simply by tuning into the Olympics, no matter how attentive a viewer. Camus may have learned all he knew about morality and obligations from football, but these lessons would have been harder to learn from the side-lines.

The ethical lessons learned by being a sports fan may be relatively modest, and in some cases, they will be too modest to notice, because similar lessons are readily available to those who dislike sport. Furthermore, because of the ubiquity of practices in human life, the virtue(s) acquired by spectatorship may be over-determined. Nevertheless, partial engagement need not be morally vacuous. If this is so, then we have grounds for optimism as it suggests that forms of employment that fall short of a deep engagement in a practice can still be morally educative to some degree, thereby broadening the possible scope of MacIntyrean analyses of business and enabling us to sidestep Hager's second scope problem.

The manager of an art gallery who admires art but lacks the abilities required to become an artist may likewise enjoy some intrinsic satisfaction from admiring the work displayed in the gallery, from making curatorial appointments based on the aesthetic merits of candidates' previous work, and may therefore receive a moral education from this relatively meagre engagement. Neither the satisfaction nor the moral education compares to that experienced by the artists themselves, but this does not mean they are non-existent. In such marginal cases, the role of the community becomes even more important than it is in more obviously paradigmatic cases, as I noted above. Indeed, in less paradigmatic cases a robust, supportive community may prove to be absolutely indispensable for the activity to be morally educative. The gifted and well-trained painter, who needs no further formal tuition, may be able to continue to deepen his or her appreciation of the relevant standards of excellence by consulting historical examples of such excellence. In marginal cases, however, discussing the internal goods of a particular practice with other practitioners may be required for a meaningful engagement with that practice, and thus for an experience of those internal goods. Membership of a practice-based community, therefore, becomes a more significant corrective and guide in cases where engagement is partial.

So, Hager's claim that it is unclear where we ought to set the limits of engagement is well founded, but it is not as damaging as it might have initially appeared. The relatively inclusive account of practice-engagement I have outlined here allows for applications of the concept in general, and, most pertinently for our concerns, to business ethics in particular because it allows those who play a variety of roles in support of a practice (e.g. managers, owners) to be accounted practitioners who are at the periphery of a practice. While the standards of excellence characteristic of productive practices are importantly different from those characteristic of paradigmatic practices, as I argued in the previous section, this asymmetry does not render 
productive activities incapable of providing intrinsic satisfaction and moral education.

By analysing the concept of engagement in a practice, we have not given an unambiguous answer to the question of who is and is not a practitioner, but we have seen why this does not pose a serious threat to the concept. Moreover, the definitive feature of practice-engagement is being motivated by the relevant internal goods, which we will come to below and which necessarily remains out of reach for the kind of conceptual argument offered in this section.

The argument developed here also broadly applies to the third of Hager's scope problems, that posed by generic activities. Hager says "is it not plausible to maintain that, say, beef production is a different practice from rice growing? It seems clear that the internal goods in the two cases would differ markedly" (2011, p. 551), and so MacIntyre's use of generic terms, 'farming', 'fishing', 'architecture', etc., may be unacceptable if we regard these different activities as possessing irreducibly diverse internal goods.

However, just as it is unnecessary to draw a definite border between those engaged in a practice and those who are not, there is no need for definite borders between related practices. Rice farming and beef farming, to continue with Hager's example, have different histories and communities, and so presumably the masters most centrally and deeply engaged in these practices will experience subtly different internal goods. However, because of the evident similarities, those whose engagement is less central may receive an identical moral education from their level of engagement. Indeed, if my analysis of partial engagement is correct, then the master rice farmer may know enough about farming as a whole to be comparable to those at the periphery of another type of farming.

Similar claims can be made about many other closely related practices. A field hockey player and an ice hockey player may possess an insight into the goods of each other's sport. A logician may have an appreciation of the goods internal to both computer science and metaphysics. So again, the impossibility of deciding on the precise scope of a practice is not a fatal weakness, but rather reflects a recognition that each practice will share key features with other, related practices and that in the case of generic activities, it is these connections that often warrant the use of a single overarching label used to categorise them. The vagueness of the definition corresponds to the open-ended nature of the activities in question. Both beef farming and rice farming are called 'farming' with good reason. Hager's scope problems do not undermine MacIntyre's concept, but nevertheless its scope remains somewhat unclear. Therefore, the following section will offer some suggestions about the applicability of the concept of practices within business ethics.

\section{Moral Education at Work}

Analysing the nature of football may give us reason to conclude that football is a practice. Certainly, it is an activity that possesses distinctive goods and can be both intrinsically satisfying and morally educative. However, the motivations of particular agents determine the extent to which football actually does provide intrinsic satisfaction or a moral education. Any list of examples of practices is, in an important sense, provisional and fallible. Even though it is difficult to imagine turnip-planting supplanting physics as an example of a paradigmatic practice, further evidence may emerge that results in a paradigm shift in our thinking about activities that are intrinsically rewarding and morally educative. Any such paradigm shift will be at least partly a result of the experience and testimony of those engaged in the activities in question, and this subjective element is essential to the concept of a practice.

To borrow Susan Wolf's phrase about meaning in life, proper engagement in a practice exists "when subjective attraction meets objective attractiveness" (2010, p. 78). Subjective satisfaction is logically secondary to the objective features which mark an activity out as a practice, but it is necessary. The activity must be complex, coherent, socially established, and so on, but the participant must at some point be motivated by the relevant internal goods to be accounted a practitioner. A footballer who performs only for the money is not engaged in football in this sense-despite actually performing that activity with a considerable degree, perhaps even an exceptional degree, of skill, as MacIntyre notes (2007, p. 274). Nevertheless, it is difficult to imagine a professional athlete only being concerned with external goods and almost impossible to imagine someone coming to have that degree of skill without a concern for the internal goods, at least to begin with. While, as Whysall points out, "modern elite sport is clearly distant from the idealistic world of fair play and amateur ideals, reflecting increasing pressures of professionalisation, commercialisation and commodification" (2014, p. 426), a love of the game may well be a prerequisite to the dedication required to become a professional footballer, which indicates the need for empirical investigation into the commitment and motivation of particular agents. So conceptual arguments can point us in the direction of areas where empirical research is likely to be fruitful. With this in mind, I will outline several possible areas of application which are likely to illustrate the potential breadth of MacIntyre's concept: (1) work focusing on narrative and MacIntyre's 'practices/institutions' framework, (2) work on small business and on trade unions which focuses on the practice of politics, (3) broader applications based on 'consumption' of work. 
Empirical investigations using MacIntyre's 'practicesinstitutions' framework (e.g. Beadle 2013; Beadle and Könyöt 2006; Moore 2012b; Robson 2015; Bernacchio and Couch 2015) have already demonstrated its usefulness. Much of this work is narrative-focused and so allows for the kinds of discussions about goods and ends which are necessary to practices, and therefore for the relationships required by a narrative that is genuinely shaped by goods internal to that practice. A narrative-focused approach provides insight into the work of people who understand themselves as subordinate to the good of the activity in question. Such studies are important and illuminating; however, I wish to suggest some other, broader avenues worthy of exploration.

One such avenue is that of small businesses. Given MacIntyre's claim that practice-based communities must be relatively small-scale and local (MacIntyre 1999), the problem of scale confronts anyone serious about applying MacIntyre's thought to modern institutions and, as I noted above, the role of the community becomes even more pronounced in cases of partial engagement, as much employment is likely to be. Furthermore, as Hendry points out, there "is evidence in particular that small companies within a geographic region see themselves not merely as competitors but as members of a moral community with reciprocal ties and obligations" (2001, p. 212), which suggests there is scope for studies which take the business, practitioners (or protopractitioners), and the local community into consideration. Furthermore, Payne et al. (2011) found that family firms are more likely to be characterised by empathy (the best indicator of genuine ethical commitment according to Batson 2011). While it is clear that not just any small business will necessarily be a practice-based community, small businesses may well be a good place to look for the moral education provided by a partial engagement in a practice, and in particular by the practice of politics. Similarly, another possible avenue for future work inspired by MacIntyre's moral theory to explore is the community provided by trade unions, which MacIntyre has claimed are "necessary for the good life under any form of capitalism" (2008a, p. 275), and even that militant trade union action is necessary to achieve even "elementary justice" in contemporary society (2016, p. 107). Trade unions are certainly concerned to sustain communal goods from the corrupting influence of institutions (even though unions, qua bureaucratic entities, can themselves be corrupting institutions), and so again are best approached as likely sites of engagement in the practice of politics.

While it may be true that some industries and some jobs are impossible to make sense of in MacIntyrean terms (for instance banking, according to MacIntyre 2015), there is reason to believe a broader application of the concept of practices is feasible, and indeed worthwhile. Even if we do not think it is likely that many contemporary organisations will be able to house practices, and even if we agree with
MacIntyre's claim that the modern economic order "provides systematic incentives to develop a type of character that has a propensity to injustice" (1995, p. xiv), we must also remember that the modern economic order cannot fully destroy the systematic incentives to develop a just character that are present in almost all human social formations, and which supports MacIntyre's claim that "plain persons are in fact generally and to a significant degree proto-Aristotelians" (1992, p. 5). This is to say even if our culture is relatively inhospitable to the virtues, as MacIntyre himself thinks, it cannot entirely undermine our moral agency and ability to acquire the virtues. Indeed, this feature of contemporary life is what prevents MacIntyre's move from discussing practices in After Virtue to discussing relatively prosaic forms of work in Ethics in the Conflicts of Modernity seeming like a radical departure. This means that even in industries and workplaces that do not focus on the pursuit of internal goods as a central aim, agents may still be able to resist the systematic incentives to injustice, and engage in both the practice of sustaining their community, and the practice which their work constitutes an engagement in, if any. This prevalence of proto-Aristotelianism provides motivation to explore how and why people choose to pursue the careers they do.

While the dominance of consumerism in our society is often regarded as being deeply undesirable because, for instance, it undermines communal life (Segal 1999), encourages the depletion of natural resources (Cohen and Murphy 2001), and corrupts children and infantilises adults (Barber 2008), consumerism itself, qua choice of goods and services in line with personal preference, need not be morally problematic. Due to changes to employment in the last few decades, such as a decrease in job security, and a flattening of organisations leading to fewer career opportunities, not to mention the demise in traditional ways of life, research into the 'psychological contract' between employers and employees (e.g. Rousseau 1995; Conway and Briner 2005; George 2009) suggests that work is now increasingly regarded as an object of consumption. Employees are now more focused on training opportunities, flexibility, and the extent to which work is fulfilling. Clearly consumerism can be good if it serves some good end rather than being an end in itself. Consider Keat's (2008) remarks on consumer goods.

One buys a loaf of bread, and then eats it at home, often sharing it with family or friends. The example is banal, but says something important: although consumer goods are 'items of private property', acquired through market transactions, they are typically enjoyed in the context of non-private, non-market activities and relationships. So if we want to understand and judge their value, we need to understand and judge what it is that they contribute to, and how significant that contribution is (or can be) (2008, p. 249). 
Here, we can see the importance of considering the 'for the sake of' reasoning that goes into the consumer's decision. An unthinking purchase of a loaf of bread as part of weekly grocery shopping may be interchangeable with a variety of similar products, whereas a carefully selected marble rye to serve at a dinner party might not be. And while the price of the marble rye is not insignificant, and certainly the consumer will not ignore it, it is not the sole or even the primary focus. MacIntyre offers the example of a child learning to play, and ultimately to appreciate, chess (2007, p. 188). In this example, the child initially plays to be rewarded with candy, but eventually comes to experience the internal goods of chess, and no longer needs the extrinsic reward.

The case of work as an object of consumption is similar. What work is done for the sake of will be telling. If it is engaged in solely for the sake of payment, it will not be engaged with as a practice irrespective of whether the activity itself satisfies the requirements of MacIntyre's definition, i.e. irrespective of its complexity, social-establishment and so on, a point made above with reference to football. If it is engaged in for some richer purpose, then it may constitute practice-engagement, even if external goods, e.g. the salary, are considered to be highly important. Garcia-Ruiz and Rodriguez-Lluesma have persuasively argued that "consumption decisions are frequently experienced as activities that are necessary for the achievement of the goods internal to practices" $(2014$, p. 525). The key point here is that consumption need not be passive, but can be informed by a virtuous conception of the good life. One prerequisite of our being able to meaningfully understand work as a potential object of virtuous consumption is that at least some degree of choice is often available to workers. Another is that workers do not simply pursue jobs which pay the highest available salary or carry the most status. Neither of these conditions is as widespread as we would no doubt like them to be, but, in developed countries at least, neither is entirely rare.

Where these conditions hold, people can display their commitment to the good life by seeking practice-based work. This may be problematic if the consumeristic, individualistic tendencies of job applicants preclude subordination to the practice or respect for the mastery of more seasoned practitioners. Empirical research might therefore draw on employee motivations, conception of the good life, etc. However, as MacIntyre's fishermen example (1994, 2008b), in which crew members join for the pay and stay for the rewarding relationships provided by the community, shows, people do not need to seek out the practice in advance in order to be able to come to appreciate its internal goods, even though they must eventually come to appreciate these goods to be engaged in the practice qua practice. If this is so, then it is likely that people seeking work that satisfies their pre-existing, untutored, but excellence-focused desires will be at least as able to appreciate the internal goods of their work, and make the sacrifices that the practice demands of them. People who, perhaps vaguely and apart from any particular practice, want to do something 'good' may well initially think in terms of subjective preferences, but they are undeniably resistant to any conception of success that focuses primarily on external goods and so may easily find themselves as 'peripheral practitioners', able to enjoy the intrinsic satisfactions and the moral education that work, at its best, can provide. Moore notes that within an organisation, there "will need to be a continuing debate about the purpose" it serves $(2017$, p. 18 ), and this may be all the invitation to engage in a practice that such recruits need, and is likely to facilitate the community that is conducive to such engagement.

Therefore, far from being inapplicable, as Hager's scope problems threaten to render it, and far from being only narrowly applicable, as a strongly historicist reading of MacIntyre's discussion of practices would suggest, there is scope to construe a wide variety of forms of work in terms of MacIntyre's concept of a practice. MacIntyre provides a robust ethical framework, and one that is not as elitist and severe as his reputation sometimes suggests. The foregoing discussion suggests that the concept of a practice is far from exclusionary and that the bar for accepting a broadly MacIntyrean account of virtue, and of moral education at work, is not as high as is sometimes thought.

Acknowledgements I would like to thank Craig Jordan-Baker and three anonymous reviewers for comments on a previous version of this paper.

\section{Compliance with Ethical Standards}

Conflict of interest The author declares that he has no conflict of interest.

Human and Animal Rights This article does not contain any studies with human participants or animals performed by any of the authors.

Open Access This article is distributed under the terms of the Creative Commons Attribution 4.0 International License (http://creativecommons.org/licenses/by/4.0/), which permits unrestricted use, distribution, and reproduction in any medium, provided you give appropriate credit to the original author(s) and the source, provide a link to the Creative Commons license, and indicate if changes were made.

\section{References}

Aristotle, (2000). The Nicomachean ethics (2nd ed.). Cambridge: Hackett.

Barber, B. R. (2008). Consumed. New York: W.W. Norton \& Company.

Batson, C. D. (2011). Altruism in humans. New York: Oxford University Press. 
Beabout, G. (2013). The character of the manager. Basingstoke: Palgrave MacMillan.

Beadle, R. (2008). Why business cannot be a practice. Analyse und Kritik, 30(1), 229-241.

Beadle, R. (2013). Managerial work in a practice-embodying institution: The role of calling, the virtue of constancy. Journal of Business Ethics, 113(4), 679-690.

Beadle, R., \& Knight, K. (2012). Virtue and meaningful work. Business Ethics Quarterly, 22(2), 433-450.

Beadle, R., \& Könyöt, D. (2006). The man in the red coat-Management in the circus. Culture and Organization, 12(2), 127-137.

Bernacchio, C., \& Couch, R. (2015). The virtue of participatory governance: A MacIntyrean alternative to shareholder maximisation. Business Ethics: A European Review, 24(S2), S130-S143.

Boden, M. A. (2003). The creative mind: Myths and mechanisms (2nd ed.). London: Routledge.

Borden, S. L. (2007). Journalism as practice: MacIntyre, virtue ethics and the press. Aldershot: Ashgate.

Brewer, K. B. (1997). Management as a practice: A response to Alasdair MacIntyre. Journal of Business Ethics, 16(8), 825-833.

Cohen, M. J., \& Murphy, J. (2001). Exploring sustainable consumption: Environmental policy and the social sciences. Oxford: Elsevier.

Conway, N., \& Briner, R. (2005). Understanding psychological contracts at work. Oxford: Oxford University Press.

D'Andrea, T. D. (2006). Tradition, rationality, and virtue: The thought of Alasdair MacIntyre. Aldershot: Ashgate.

Dawson, D. (2014). Two forms of virtue ethics: Two sets of virtuous action in the fire service dispute? Journal of Business Ethics, 128(3), 585-601.

Dobson, J. (2009). Alasdair MacIntyre's Aristotelian business ethics: A critique. Journal of Business Ethics, 86(1), 43-50.

Dunne, J. (2003). Arguing for teaching as a practice: A reply to Alasdair MacIntyre. Journal of Philosophy of Education, 37(2), 353-369.

Feldman, S. (1986). Objectivity, pluralism and relativism: A critique of MacIntyre's theory of virtue. Southern Journal of Philosophy, 24(3), 307-319.

Ferrero, I., \& Sison, A. J. G. (2014). A quantitative analysis of authors, schools and themes in virtue ethics articles in business ethics and management journals (1980-2011). Business Ethics: A European Review, 23(4), 375-400.

Garcia-Ruiz, P., \& Rodriguez-Lluesma, C. (2014). Consumption practices-A virtue ethics approach. Business Ethics Quarterly, 24(4), 509-531.

George, C. (2009). The psychological contract. Maidenhead: Open University Press.

Hager, P. (2011). Refurbishing MacIntyre's account of practice. Journal of Philosophy of Education, 45(3), 545-561.

Hartman, E. M. (2013). The virtue approach to business ethics. In D. Russell (ed.) The Cambridge Companion to Virtue Ethics, (pp. 240-264). Cambridge University Press: Cambridge.

Hartman, E. M. (2015). Virtue in business: An Aristotelian approach. Cambridge: Cambridge University Press.

Hauerwas, S., \& Waddell, P. (1982). Review of after virtue. The Thomist, 46(2), 313-323.

Hendry, J. (2001). After Durkheim: An agenda for the sociology of business ethics. Journal of Business Ethics, 34(3-4), 209-218.

Kay, J. (1997). A stakeholding society-What does it mean for business? Scottish Journal of Political Economy, 44(4), 425-436.

Keat, R. (2008). Ethics, markets, and MacIntyre. Analyse und Kritik, $30(1), 243-257$.

Keat, R. (2015). Towards a critical ethical economy. In A. Bielskis \& K. Knight (eds.), Virtue and Economy: Essays on Morality and Markets, (pp. 191-211). Ashgate Publishing.
Knight, K. (2008). Practices: The Aristotelian concept. Analyse und Kritik, 30(1), 317-329.

Knight, K. (2009). MacIntyre's progress. Journal of Moral Philosophy, $6(1), 115-126$.

Knight, K. (2013). MacIntyre's Revolutionary Aristotelianism: Pragmatism opposed, Marxism outmoded, Thomism transformed. In F. O'Rourke (ed.), What Happened in and to Moral Philosophy in the Twentieth Century?: Philosophical Essays in Honor of Alasdair MacIntyre, (pp. 83-121). University of Notre Dame Press.

Lawton, A., \& Páez, I. (2014). Developing a framework for ethical leadership. Journal of Business Ethics, 130, 639-649.

Leeper, R., \& Leeper, K. (2001). Public relations as practice: Applying the theory of Alasdair MacIntyre. Public Relations Review, 27(4), 461-473.

Lutz, C. (2004). Tradition in the ethics of Alasdair MacIntyre. Plymouth: Lexington.

MacIntyre, A. (1988). Whose justice? Which rationality?. London: Duckworth.

MacIntyre, A. (1990). Three rival versions of moral enquiry. London: Duckworth.

MacIntyre, A. (1992). Plain persons and moral philosophy. American Catholic Philosophical Quarterly, 66(1), 3-19.

MacIntyre, A. (1994). A partial response to my critics. In J. Horton \& S. Mendus (eds.), After MacIntyre: Critical Perspectives on the Work of Alasdair MacIntyre, (pp. 283-384). Polity Press: Cambridge.

MacIntyre, A. (1995). Christianity and marxism (2nd ed.). London: Duckworth.

MacIntyre, A. (1999). Dependent rational animals. Chicago: Open Court.

MacIntyre, A. (2007). After virtue (3rd ed.). London: Duckworth.

MacIntyre, A. (2008a). What more needs to be said? A beginning, although only a beginning, at saying it. Analyse und Kritik, 30(1), 261-281.

MacIntyre, A. (2008b). How Aristotelianism became revolutionary: Ethics resistance and Utopia. Philosophy of Management, 7(1), 3-7.

MacIntyre, A. (2013). Replies. Revue Internationale de Philosophie, 67(2), 201-220.

MacIntyre, A. (2015). The Irrelevance of Ethics. In A. Bielskis \& K. Knight (eds.), Virtue and Economy: Essays on Morality and Markets, (pp. 7-21). Ashgate Publishing.

MacIntyre, A. (2016). Ethics in the conflicts of modernity. Cambridge: Cambridge University Press.

McPherson, D. (2013). Vocational virtue ethics: Prospects for a virtue ethic approach to business. Journal of Business Ethics, 116(2), 283-296.

Miller, D. (1994). Virtues, practices and justice. In J. Horton \& S. Mendus (eds.), After MacIntyre: Critical Perspectives on the Work of Alasdair MacIntyre, (pp. 245-264). Polity Press: Cambridge.

Moore, G. (2002). On the implications of the practice-institution distinction: MacIntyre and the application of modern virtue ethics to business. Business Ethics Quarterly, 12(1), 19-32.

Moore, G. (2012a). The virtue of governance, the governance of virtue. Business Ethics Quarterly, 22(2), 293-318.

Moore, G. (2012b). Virtue in business: Alliance boots and an empirical exploration of MacIntyre's conceptual framework. Organization Studies, 33(3), 363-387.

Moore, G. (2015). Corporate character, corporate virtues. Business Ethics: A European Review, 24(S2), S99-S114.

Moore, G. (2017). Virtue at work: Ethics for individuals, managers, and organizations. Oxford: OUP.

Muirhead, R. (2004). Just work. London: Harvard University Press.

Mumford, S. (2012). Watching sport: Aesthetics, ethics and emotion. London: Routledge. 
Nicholas, J. (2012). Reason, tradition and the good: MacIntyre's tradition-constituted reason and Frankfurt School critical theory. Notre Dame: UNDP.

Payne, G. T., Brigham, K. H., Broberg, J. C., Moss, T. W., \& Short, J. C. (2011). Organizational virtue orientation and family firms. Business Ethics Quarterly, 21(2), 257-285.

Pfeffer, J., \& Sutton, R. I. (2006). Hard facts, dangerous half-truths, and total nonsense: Profiting from evidence-based management. Boston: Harvard Business School Press.

Robson, A. (2015). Constancy and integrity: (un) measurable virtues? Business Ethics: A European Review, 24(S2), S115-S129.

Rousseau, D. (1995). Psychological contracts in organizations: Understanding written and unwritten agreements. London: Sage Publications.

Segal, J. M. (1999). Graceful simplicity: Toward a philosophy and politics of simple living. New York: H. Holt and Co.
Sellman, D. (2000). Alasdair MacIntyre and the professional practice of nursing. Nursing Philosophy, 1(1), 26-33.

Sinnicks, M. (2014). Practices, governance and politics: Applying MacIntyre's ethics to business. Business Ethics Quarterly, 24(2), 229-249.

Wachbroit, R. (1985). Relativism and virtue. The Yale Law Journal, 95, 1559-1565.

West, A. (2016). After virtue and accounting ethics. Journal of Business Ethics. https://doi.org/10.1007/s10551-016-3018-9.

Whysall, P. (2014). Reflections on ethics, sport and the consequences of professionalization. Business Ethics: A European Review, 23(4), 416-429.

Wolf, S. (2010). Meaning in life and why it matters. Princeton, NJ: Princeton University Press.

Wyma, K. D. (2015). The case for investment advising as a virtuebased practice. Journal of Business Ethics, 127(1), 231-249. 